УДК $37.02+81: 39$

DOI https://doi.org/10.32782/apv/2021.1.12

\title{
Наталія ІОВХІМЧУК
}

кандидат філологічних наук, доцент кафедри теорії та методики початкової освіти, Волинський національний університет імені Лесі Українки, просп. Волі, 13, м. Луцьк, Волинська обл., Україна, 43025

ORCID: 0000-0002-4617-3535

Бібліографічний опис статті: Іовхімчук, Н. (2021). Збагачення мовлення молодших школярів лінгвоукраїнознавчою лексикою. Acta Paedagogica Volynienses, 1, 68-72, doi: https://doi.org/10.32782/apv/2021.1.12

\section{ЗБАГАЧЕННЯ МОВЛЕННЯ МОЛОДШИХ ШКОЛЯРІВ ЛІНГВОУКРАЇНОЗНАВЧОЮ ЛЕКСИКОЮ}

У статті з'ясовано проблему збагачення мовлення молодших школярів лінгвоукраӥнознавчою лексикою. Проте актуальною залишається низка суперечностей між: зростанням необхідності різнобічно формувати національно-мовну, етнокультурну особистість молодшого школяра та мінімальною реалізацією изього процесу в сучасній початковій школі. Визначено поняття «лексика» як змістовий і найдинамічніший компонент мовлення, «лінгвоукраӥнознавча лексика молодшого школяра» - словниковий запас учня, щзо відображає національне світосприйняття українського народу і сприяє формуванню етномовленнєвих умінь і навичок на уроках украӥнської мови. Метою таких уроків є підвести учнів до поглибленого вивчення украӥнської пісні, традицій, звичаїв, природи рідного краю; ознайомити учнів із поняттями: "рідна мова», «українська мова», «корінні українські слова», «запозичені слова»; стимулювати учнів до вивчення слів лінгвоукраїнознавчого змісту, використовувати їх у власному мовленні. Наведено приклади вправ на збагачення, активізацію активного і пасивного словника учнів. Основними типами вправ на уроках української мови мають слугували вправи на тематичне групування слів; синонімізацію; читання тексту з виписуванням етнолексем; добір власних прикладів; з'ясування сполучуваності лінгвоукраїнознавчих слів з іншими словами; обтрунтування висновків; заміну в тексті мовних одиниць; складання словосполучень, речень за опорними словами; побудова монологів та діалогів; підбір слів до певної мовленнєвої ситуацї; робота зі словником, вправи на оцінно-контрольні дї.

Ключові слова: лексика, лінгвоукраӥнознавство, лінгвоекраїнознавча лексика молодшого школяра, без еквівалентна лексика, украӥнознавчий компонент.

\section{Nataliia IOVKHIMCHUK}

PhD in Philology, Senior Lecturer at the Department of Theory and Methods of Primary Education, Lesya Ukrainka Volyn National University, 13 Voli ave., Lutsk, Volyn region, Ukraine, 43025

ORCID: 0000-0002-4617-3535

To cite this article: Iovkhimchuk, N. (2021). Zbahachennia movlennia molodshykh shkoliariv linhvoukrainoznavchoiu leksykoiu [Enrichment of speech of junior schoolchildren by language-Ukrainian vocabulary]. Acta Paedagogica Volynienses, 1, 68-72, doi: https://doi.org/10.32782/apv/2021.1.12

\section{ENRICHMENT OF SPEECH OF JUNIOR SCHOOLCHILDREN BY LANGUAGE-UKRAINIAN VOCABULARY}

The article clarifies the problem of enriching the speech of junior schoolchildren with linguistic-Ukrainian vocabulary. However, a number of contradictions remain relevant: the growing need to comprehensively form the national-linguistic, ethnocultural personality of the junior school student and the minimal implementation of this process in the modern primary school. The concept of "vocabulary" is defined as the semantic and most dynamic component of speech, "linguistic-Ukrainian vocabulary of junior schoolchildren" - a student's vocabulary that reflects the national worldview of the Ukrainian people and promotes the formation of ethnolinguistic skills in Ukrainian language lessons. The purpose of such lessons is to bring students to an in-depth study of Ukrainian song, traditions, customs, nature of the native land; to acquaint students with the concepts: "native language", "Ukrainian language", "native Ukrainian words", "borrowed words"; to stimulate students to study words of linguistic-Ukrainian content, to use them in their own speech. Examples of exercises for enrichment, activation of active and passive vocabulary of students are given. The main types of exercises in Ukrainian language lessons should be exercises on thematic grouping of words; 
synonymization; reading the text with the writing of ethno tokens; selection of own examples; elucidation of compatibility of linguistic-Ukrainian words with other words; substantiation of conclusions; replacement of language units in the text; composing phrases, sentences based on key words; construction of monologues and dialogues; selection of words for a certain speech situation; work with the dictionary, exercises for evaluation and control actions.

Key words: vocabulary, linguo-Ukrainian studies, linguo-local history vocabulary of a junior schoolchild, without equivalent vocabulary, Ukrainian studies component.

Постановка проблеми. Розвиток освіти і культури неможливі без національного самоусвідомлення народу, засвоєння українцями культурної спадщини попередніх поколінь, оволодіння словниковим багатством рідної мови.

У науковому обігу проблема збагачення словникового запасу лінгвоукраїнознавчими словами в початковій школі представлена дослідженнями питань словникової роботи: О. Білецький, А. Богуш, М. Вашуленко, В. Мельничайко, М. Пентилюк тощо.

Незважаючи на широкий спектр досліджуваних питань, проблема збагачення мовлення молодших школярів лінгвоукраїнознавчою лексикою залишається очевидною низка суперечностей між: зростанням необхідності різнобічно формувати національно-мовну, етнокультурну особистість школяра та мінімальною реалізацією цього процесу в сучасній початковій школі.

Основний виклад матеріалу. Поняття “лексика" тлумачиться як “словниковий склад, сукупність слів якоїсь мови чи діалекту” $[1$, c. 272]. Лексика - змістовий і найдинамічніший компонент мовлення. При одному й тому самому рівні оволодіння граматикою мови, інтонаційними засобами мовлення вона може бути найрізноманітнішою щодо своєї кількісної і якісної досконалості. Як зазначає I. Синиця, лексика найповніше і найточніше репрезентує особистість мовця, іiі розумовий розвиток, стан iï загальної і мовленнєвої культури [4, с. 37].

Мова як прояв національної самобутності народу зберігає і передає наступним поколінням етнічні особливості світосприймання, картини соціального та культурного побуту, народні думки і почуття, звичаї та обряди, втілені у відшліфованих словесно-виражальних формах.

Народ формує власну мовну картину світу, відбиває в ній своє світосприймання, специфіку свого життя, культури, реакції на довкілля, оцінки тієї чи тієї реалії. “Оскільки мовна модель $€$ постійним предметом пізнання, то пізнання світу проходить через процеси пізнання передусім мовного організму в його динаміці, вічному поруху, взаємозв'язках мовних явищ. Єдність мови, мислення і мовної свідомості необхідно продуктивно розглядати в руслі семантики мовних явищ” [3, с. 10].

Мова виконує важливу етнотворчу та етнооб'єднувальну функції; найповніше пов'язана 3 культурно-побутовими особливостями етносів, бо їхня культура, особливо духовна, найповніше виражається рідною мовою. Більше того, мова входить у культуру етносів, зберігає і передає способи їхнього мислення і психологію [6, с. 160]. "Культура - це сфера духовного життя суспільства, що охоплює систему виховання, освіти, духовної творчості, установи й організації, що забезпечує іiі функціонування" [6, с. 167]. Мова є могутнім чинником відображення об'єктивної дійсності в національній свідомості. 3 ії допомогою формується лінгвокультурна картина світу, що є продуктом і рушієм національної самосвідомості. Водночас мова $\epsilon$ тим чинником, який єднає духовні надбання попередніх і сучасних поколінь, а також пов'язує окрему людину-мовця з цілим народом - носієм мови.

Проблеманаціонально-культурноїспецифіки в значенні слова в сучасній лінгвістиці висвітлюється у двох аспектах: лінгвокраїнознавчому та перекладознавчому. Лінгвокраїнознавство досліджує мову 3 погляду іiі взаємозв'язку 3 культурою у двох взаємопов'язаних напрямах: філологічному (лінгвістичному) та лінгводидактичному (методичному). Предметом дослідження філологічного напряму $є$ аналіз мови 3 метою виявлення в ії складі лексичних одиниць із національно-культурною семантикою. Під час вивчення української мови певне місце повинно займати знайомство 3 культурою, минулим і сучасним українського народу, а вчитель повинен володіти системою знань, названою «українознавством» (система етнологічних, культурологічних, етнопедагогічних, історичних та ін. досліджень про український народ у його минулому та сучасному розвитку).

Лінгвокультурологічне бачення прямих i зворотних зв'язків між семантикою слова, 
а також усім ореолом його конотативних сенсів, динамічних асоціацій та й ширше соціокультурною реальністю задекларовано ще в концепції О. Потебні, працях Л. Булаховського, І. Огієнка та інших учених. В. Загороднова поділяє етнокультурознавчу лексику таким чином: 1. Еквівалентні лексеми, в яких зміст інформації українського слова на рівні лексичного поняття і лексичного фону збігається зі словом іншої мови (наприклад, російської чи білоруської) (сонце, вітер, вода, земля, мати, хліб, день). Такі слова у своєму основному значенні не залежать від національно-культурної специфіки, для їх пояснення достатньо такого способу семантизації, як переклад. 2. Безеквівалентні лексеми називають поняття, специфічні для певної культури, для яких немає точного відповідника в іншій мові. Розуміння таких лексем пов'язане із з'ясуванням тієї змістової інформації, яку закладено в цих лексичних одиницях і на рівні лексичного поняття, i на рівні лексичного фону. У змісті і структурі безеквівалентної лексики виділяє: - центр: слова-реалії, тобто лексеми, які не мають аналогів в інших мовах через відсутність об'єктів найменування (наприклад, галушки, чумак, оселедець); - периферія: фонові слова, тобто лексеми, якими в одній із етнокультур поняття про ті самі або подібні явища чи стани об'єктів довколишнього світу (матеріального і духовного) фіксуються детальніше або дещо інакше, ніж в іншій. Наприклад, укр. провесінь - рос. канун весны; укр. напровесні - рос. в начале весны; укр. дятел, дятленя (пташеня дятла); коваль - ковалиха (дружина коваля) - ковалівна (донька коваля) - коваленко (син коваля); пшонина (зернина пшона), житнище (поле, на якому росло жито), гречаниця (гречана солома). 3. Слова-символи - слова, що мають усталені асоціативні зв'язки з відповідним поняттям. Значення символів не має чітко окреслених контурів, воно пов'язане 3 мовною метафорою [5, с. 69].

Українські лексичні одиниці, що передають національний колорит, національний менталітет, становлять досить неоднорідний шар. Узагальнюючи попередні думки дослідників щодо сутності лінгвоукраїнознавчої лексики, аналізуючи лінгвістичні, етнологічні, історичні та словникові джерела можна визначити, що лінгвоукраїнознавство - спеціальна технологія подання українознавчих знань культурного й мовного планів на уроках української мови, що орієнтує на творчий підхід, пошук відповідних текстів, створення методичного апарату. На уроках української мови це знаходить відбиток у показі краси й можливостей мови. Така технологія дає змогу розвивати мовлення й мислення учнів початкових класів, формувати та збагачувати їхню образно-емоційну пам’ять.

Лінгвоукраїнознавча лексика молодшого школяра - це словниковий запас учня, що відображає національне світосприйняття українського народу і сприяє формуванню етномовленнєвих умінь і навичок на уроках рідної мови.

Щодо тематичної класифікації лінгвоукраїнознавчої лексики, то тут також немає одностайності думок учених. Так, В. Жайворонок нараховує двадцять шість предметно-тематичних груп безеквівалентної та фонової лексики. Найбільш численними є групи слів - найменувань предметів духовної культури: музичних інструментів, міфічних та демонічних істот, етнонімів; географічних реалій; предметів матеріальної культури: одягу, взуття, страв.

Аналіз поданих класифікацій зумовив поділ лінгвоукраїнознавчої лексики для вивчення у початковій школі. Так, національно позначені слова класифікуємо на слова-символи, слова українського мовленнєвого етикету та тематичні групи етнолексем.

На думку С. Срмоленко та Л. Мацько, у навчальному змісті мають бути представлені такі змістові лінії, які дозволяють школярам краще пізнати свою країну, іiі народ, культуру та традиції, усвідомити унікальність рідної мови через інформацію про її походження та історію $[2$, с. 29]. Українознавчий компонент - це складова навчально-виховного процесу, яка включає знання про Україну, іiї мову, природу, екологію, культуру, родовід, історію рідного краю тощо. Щодо збагачення словника учнів початкових класів лінгвоукраїнознавчою лексикою варто проводити українознавчі уроки. Метою таких уроків $€$ підвести учнів до поглибленого вивчення української пісні, традицій, звичаїв, природи рідного краю; ознайомити учнів із поняттями: “рідна мова”, “українська мова”, “корінні українські слова", “запозичені слова"; стимулювати учнів до вивчення слів лінгвоукраїнознавчого змісту, використовувати їх у власному мовленні.

Ознайомлення 3 лінгвоукраїнознавчої лексикою на уроках української мови має здійснюва- 
тись у певній послідовності: сприймання нового слова: знаходження невідомого слова в тексті, ребусі, кросворді; дидактичні ігри; розгадування загадок; знаходження невідомих слів у приказках, прислів'ях, повідомлення слова вчителем; усвідомлення лексичного значення слів: етимологічна довідка; звуко-буквенний аналіз слова; вимова; показ предмета, позначуваного цим словом чи малюнка; пояснення, розповідь, бесіда; запис слова, позначення наголосу; запам'ятовування лексичного значення слів: повторення слів хором, поодинці; вивчення віршів, скоромовок, прислів'їв з цими словами; складання опису предмета, позначуваного словом; складання речень, словосполучень; малювання предметів, позначуваних словами, що вивчались. Запам'ятовування лексики найефективніше досягалось у процесі мовленнєвої діяльності; відтворення засвоєних слів в усному чи писемному мовленні. При використанні слів у відтворюваних видах мовленнєвої діяльності учневі необхідно було виконати такі дії: пригадати слово; вимовити його; включити у сполучення на основі смислової узгодженості й відповідно до граматичних норм; включити словосполучення в речення, текст.

Основними типами вправ на уроках української мови мають слугували вправи на тематичне групування слів; синонімізацію; читання тексту з виписуванням етнолексем; добір власних прикладів; з'ясування сполучуваності лінгвоукраїнознавчих слів з іншими словами; обгрунтування висновків; заміну в тексті мовних одиниць; складання словосполучень, речень за опорними словами; побудова монологів та діалогів; підбір слів до певної мовленнєвої ситуації; робота зі словником, вправи на оцінно-контрольні дії.

Наведемо приклади вправ на збагачення, активізацію та уточнення активного і пасивного словника учнів.

1. 3'ясувати значення фразеологізмів: колупати піч, зробити решето, піймати гаву. Після цього дітей запитати: "У яких мовних ситуаціях можуть бути використані ці фразеологізми?”, “Чи можна замінити їх синонімами?”. “Замініть.”. “Скласти речення з одним із фразеологізмів".

2. Замінити слова за принципом “одинбагато”: козак, лелека, дуб, тополя, галунка, жайворонок, веснянка, ікона, голуб”. “Скласти словосполучення зі словами".
3. Скласти казку, придумуючи кожен по одному реченню. Після цього діти придумували назву казки.

4. Підібрати прикметники до етнолексеміменників, визначати у прислів'ях та приказках підмет і присудок.

5. Пригадати за поданим символічним значенням назву рослини або птаха:

Символом чоловічої краси та сили $є$...

Символом життя і безсмертя людської душі є ...

Символом красивої здорової дівчини $€ \ldots$

Символом мудрості $є$...

Після цього дітей запитати, які ще словасимволи їм відомі.

Щоб визначити обізнаність учнів 3 лінгвоукраїнознавчою лексикою можна використати такі завдання:

1. "Назви предметів” (подаються малюнки iз зображенням криниці, глека, куманця, кобзи, вишиванки, кресані, бандури, постолів, фуркала, млина).

2. “Слова вітання українців”, щоб виявити обізнаність дітей зі словами вітання під час християнських свят ( Христос Воскрес! Воістину воскрес! Христос ся рождає! Славімо Христа! Христос хрестився! У річці Йордані! Слава Ісусу Христу! Слава Господу Богу! Слава навіки Богу! Дай Боже здоров'я! Учнів запитати: “Які слова вітання вживають українські християни на свято: Пасхи, Різдва, Водохреща, у неділю, у будний день?”.

3. “Мовленнєвий етикет”, щоб з'ясувати обізнаність учнів із формулами українського мовленнєвого етикету під час спілкування зі співрозмовником (Хай щастить! Сердечне спасибі! Прошу вибачення. До зустрічі! Здоровенькі були! Бажаю Вам всього доброго! Здоров'ячка доброго! Щасливої дороги! Даруйте мені! Шкодую, що не зміг допомогти). Дітям розповісти, які слова мовленнєвого етикету вони вживають у ситуаціях, коли їм кажуть: “Хай щастить!”, “Сердечне спасибі!”, “Прошу вибачення!", “До зустрічі!”, “Здоровенькі були!”, “Бажаю Вам всього доброго!”, “Здоров’єчка доброго!”, “Щасливої дороги!”, “Даруйте мені!”, “Шкодую, що не зміг допомогти.”

4. “Українські народні пісні”, з'ясувати розуміння дітей етнолексем-назв календарно-обрядових пісень українського народу (коломийка, колискова, веснянка, щедрівка, колядка, гаївка, купальська пісня, весільна пісня, дума). Для дітей 
створюється ігрова ситуація. Кожному учневі пропонується роль ведучого українського телеканалу, де треба розповісти про український фольклор (коломийки, колискові, веснянки, щедрівки, колядки, гаївки, купальські пісні, весільні пісні).

5. 3'ясувати розуміння учнями символічного значення слів 3 лінгвоукраїнознавчим значенням (калина, дуб, яйце, верба, зозуля, рушник, хліб, ластівка, хата, лелека).

6. Пояснити значення фразеологізмів: виявити співвідношення розуміння дітьми фразеологічних зворотів, що містять лексеми та лексичного значення слів: глек, гава, мак, тин, вареник, кутя, макогін, діжа, ціп, віл.

7. Дібрати синоніми до фразеологізмів: зав'язати хустку, як чорний віл у ярмі робити, до чужого проса не пхай свого носа, решетом у воді зірки ловити, врізати дуба, й кочергою не дістанеш, ловити граків, почім ківш лиха, ноїв ковчег, $з$ колиски до могили.

8. Скласти речення із фразеологізмами: дати хропака, втерти носа, зарубати на носі, не по кишені".

9. Написати лист-прохання другові, використовуючи слова: маю до тебе прохання; здраствуй; красно дякую; якщо твоя ласка.

При ознайомленні із фразеологізмами, що містять етнолексеми, діти дізнавалися про те, що в українській мові є поєднання слів, які не можна розривати, вони мають цілісне значення. При вивченні етнолексем у фразеологізмах учні ознайомлювались 3 прямим їх значенням у непрямому значенні фразеологічного виразу. Наприклад, при вивченні фразеологізму “ловити гав", що означає марно витрачати час, нічим не займатися, спочатку було ознайомлено учнів $з$ прямим лексичним значенням слова “гава". Дітям демонструвалося зображення птаха, позначеного цим словом. Потім учні вчилися розкривати непряме значення фразеологізму “ловити гав”.

Висновки. Отже, лінгвоукраїнознавча лексика молодшого школяра - це словниковий запас учня, що відображає національне світосприйняття українського народу і сприяє формуванню українознавчих умінь і навичок на уроках української мови. 3'ясовано певні тенденції збагачення словникового запасу молодших школярів лінгвоукраїнознавчою лексикою. 3-поміж них: міцність запам'ятовування лексичного матеріалу залежить від раціонального поєднання вправ мовного та мовленнєвого характеру, їх максимальною насиченістю українознавчим матеріалом, застосування словників-мінімумів; активізація засвоєних етнолексем у мовленні учнів визначається адекватною мотивацією щодо ситуації спілкування, пошуковою діяльністю дітей.

\section{ЛIТЕРАТУРА:}

1. Ганич Д., Олійник І. Словник лінгвістичних термінів. Київ : Вища школа, 1985. 360 с.

2. Срмоленко С., Мацько Л. Навчально-виховна концепція вивчення української (державної) мови. Початкова школа. 1995. № 1. С. 28-33.

3. Огієнко І. Історія української літературної мови. К. : Наша культура і наука, 2004. 436 с.

4. Синиця І. Психологія усного мовлення. К. : Радянська школа, 1974. С. 36-42.

5. Словник-довідник з української лінгводидактики : навч. посіб. / кол. авторів за ред. М. Пентилюк. К. : Ленвіт, 2003. 149 с.

6. Тиводар М. Етнологія : навч. посіб. Львів : Світ, 2004. 624 с.

\section{REFERENCES:}

1. Hanych D., Oliinyk I. Slovnyk linhvistychnykh terminiv. K. : Vyshcha shkola, 1985. 360 s. [in Ukrainian].

2. Yermolenko S., Matsko L. Navchalno-vykhovna kontseptsiia vyvchennia ukrainskoi (derzhavnoi) movy. Pochatkova shkola. 1995. \# 1. S. 28-33. [in Ukrainian].

3. Ohiienko I. Istoriia ukrainskoi literaturnoi movy. Kyiv : Nasha kultura i nauka, 2004. 436 s. [in Ukrainian].

4. Synytsia I. Psykholohiia usnoho movlennia. Kyiv : Radianska shkola, 1974. S. 36-42. [in Ukrainian].

5. Slovnyk-dovidnyk z ukrainskoi linhvodydaktyky : navch. posib. / kol. avtoriv za red. M. Pentyliuk. K. : Lenvit, 2003. 149 s. [in Ukrainian].

6. Tyvodar M. Etnolohiia : navch. posib. Lviv : Svit, 2004. 624 s. [in Ukrainian]. 